\title{
O INSTITUTO DO PROTESTO NO DIREITO LUSO-BRASILEIRO E SUA IMPORTÂNCIA COMO SISTEMA DE PACIFICAÇÃO SOCIAL.
}

\author{
Ivy Helene Lima Pagliusi ${ }^{1}$ \\ Kátia Borges dos Santos ${ }^{2}$
}

\section{RESUMO}

O presente artigo versa sobre o instituto do protesto e sua normatização no sistema jurídico lusitano e brasileiro. Tendo como objetivo principal a análise de sua aplicabilidade em ambos os sistemas como instrumento de pacificação social. Pondera a atuação dos cartórios de protesto na execução de medidas de prevenção de litígios alusivos a cobranças de dívidas, tendo em vista o número elevado de pleitos que envolvem execuções por inadimplência. Observa assim a importância de evoluir a abrangência do protesto para alcançar meios alternativos de recebimento do crédito que não o meio judicial, posto que existe uma necessidade social pela desjudicialização.

Palavras-chave: Protesto. Sistema Brasileiro. Sistema Português. Pacificação Social.

\section{THE INSTITUTE OF PROTEST IN LUSO-BRAZILIAN LAW AND ITS IMPORTANCE AS A SYSTEM OF SOCIAL PACIFICATION.}

\begin{abstract}
This article deals with the protest institute and its normatization in the Lusitanian and Brazilian legal system. Its main objective is to analyze its applicability in both systems as an instrument of social pacification. It considers the performance of protest notices in the execution of measures for the prevention of litigation referring to debt collection, in view of the large number of lawsuits involving foreclosures. It thus observes the importance of evolving the scope of the protest to reach alternative means of receiving credit other than the judiciary, since there is a social need for desejudicialization.
\end{abstract}

Keyword: Protest. Brazilian System. Portuguese System. Social Pacification.

\section{INTRODUÇÃO}

\footnotetext{
1 Doutoranda em Direito pela Faculdade Autônoma de Direito - FADISP/SP e pela Universidade de Salamanca/ES. Mestranda e Doutoranda em Ciências Jurídicas pela Universidade Autónoma de Lisboa - UAL. Mestre em Direito pela Escola Paulista de Direito - EPD. Pós-Graduada em Processo Civil, Direito Civil e Direito do Consumidor e em Direito Notarial e Registral. Graduada em Direito pela Pontifícia Universidade Católica de São Paulo - PUC/SP; Tabeliã de Notas e Protesto de Letras Títulos em Ourinhos, Estado de São Paulo;

${ }^{2}$ Mestranda Direito, Políticas Públicas e Desenvolvimento Regional do Centro Universitário do Estado do Pará CESUPA. Pós-graduada em Direito Civil e Processual Civil; Pós-graduada em Direito Público; MBA em Agronegócios; Graduada em Direito pela Universidade Federal do Maranhão. Tabeliã no Estado do Pará;
} 
O estudo traça um panorama de análise entre os sistemas legislativos do Brasil e de Portugal acerca do instituto do protesto como mecanismo de pacificação social. Nesse sentido, analisa o histórico legislativo de ambos os países e como tem sido tratado o instituto de protesto como meio de persecução de créditos inadimplidos.

Em que pese ambos os países serem signatários da Lei Uniforme de Genebra ${ }^{3}$, que regulamenta normas gerais em matéria de letras de câmbio e notas promissórias, os países fazem de maneiras distintas e com tratamento diferenciado a operação do instrumento do protesto.

A pesquisa foi realizada a fim de traçar um panorama de aplicação do instituto do protesto em ambos os sistemas, e avaliar o modo como sua irradiação e efeitos refletem na construção de negócios jurídicos sólidos. Foram utilizados os métodos de abordagem dedutivo e dialético. Feito um levantamento histórico sobre o assunto passamos a analisar a prática notarial do protesto nos dois países.

Com a exame da legislação em referência busca-se verificar como o protesto tem sido tratado como mecanismo na prevenção de litígios, posto que são dois países com culturas e economias diferentes, ainda que adotem um sistema notarial de origem remota comum.

Em sociedades a cada dia mais plurais e envoltas com uma variada construção de negócios contratuais que geram obrigações, e em decorrências das mesmas, conflitos, encontrar ou mesmo solidificar no arcabouço jurídico instrumentos de pacificação social tem sido o desafio encontrado pela comunidade em geral e pelas instituições públicas e privadas que lidam diariamente com a solução pacífica de controvérsias.

\section{PROTESTO NO SISTEMA BRASILEIRO}

\subsection{Conceito e evolução do instituto}

Protesto é o ato formal e solene por meio do qual se demonstra a inadimplência ou descumprimento de uma obrigação que verse sobre direito cambiário. Certifica-se, portanto, a impontualidade do pagamento por um agente dotado de fé pública devidamente investido na função.

\footnotetext{
${ }^{3}$ Lei Uniforme de Genebra, incorporada pelo Brasil através do Decreto no 57.663, em 24 de janeiro de 1966, e por Portugal através do Decreto Lei 23.721, em 29 de março de 1934.
} 
No direito português é definido como o "acto cambiário pelo qual se comprova, sob forma autêntica, a negativa de pagar ou aceitar uma letra", nos termos do CNP editado em 1973 pela DGRN. No direito brasileiro vem nos seguintes dizeres: "é o ato formal e solene pelo qual se prova a inadimplência e o descumprimento de obrigação originada em títulos e outros documentos de dívida", nos moldes do artigo $1^{\circ}$ da Lei de Protestos brasileira.

Este instituto tem origem no século XIX a partir do desenvolvimento e expansão dos atos de comércio em razão da crescente utilização das letras de câmbio. A criação deste título propiciava a circulação de crédito por meio de três figuras: sacador, que é aquele que dá a ordem de pagamento; o sacado, que é a pessoa a quem a ordem é dirigida; e o tomador, o beneficiário da ordem.

Ocorre que o pagamento da letra de câmbio condiciona-se ao aceite do sacado, que é um ato facultativo. Logo, quando não sobrevinha o aceite, tampouco acontecia o pagamento, contra a recusa adotou-se o costume do tomador comparecer perante o notário para atestar a mora do sacador diante de uma testemunha.

O instituto do protesto evoluiu desde aquele período até os dias atuais de modo a não apenas testificar a demora, mas a falta de pagamento. Com o incremento do comércio em larga escala, surgem outros títulos de crédito, entre eles, o cheque, a nota promissória e a duplicata, que são os principais títulos de crédito da atualidade.

Quanto à evolução do instituto, pontua Sérgio Luiz José Bueno:

O protesto, dessa forma, nasceu motivado pela figura do aceite na letra de câmbio, voltado apenas para suprir sua falta, mas amadureceu e evoluiu para testificar também o descumprimento da obrigação cambiária. Com o tempo, a utilização da letra de câmbio cedeu espaço a outros títulos, e a falta de aceite paulatinamente deixou de ser o motivo mais evocado para o protesto, passando a preponderar o ato lavrado por falta de pagamento. (BUENO, 2017, p. 28)

Em Portugal, todavia, a instituição protesto não acompanhou o mesmo desdobramento sucedido no Brasil e na prática segue relegado a uma função testificadora, qual seja, de ser apenas um pressuposto formal da ação de regresso nas letras de câmbio e demais títulos de crédito sujeitos a protesto.

Em outras palavras, significa dizer que o protesto é ato facultativo da parte, haja vista que, via de regra, é dispensado para que a parte possa ingressar com a ação competente. 
Assim, o regime do protesto, de acordo com a diretriz portuguesa, é ato necessário para que seja exercitável o direito de regresso contra os demais coobrigados nas letras de câmbio.

Nessa toada, depreende-se que forçosamente o credor deverá ingressar no Judiciário para recebimento do valor devido acaso não haja a retirada da letra dentro do prazo legal, isto é, antes do protesto.

$\mathrm{Na}$ via reversa caminha o protesto no Brasil, que vem sendo cada vez mais utilizado na prática para recuperação de créditos, uma vez que o mesmo acarreta inscrição do nome do devedor e eventuais coobrigados no cadastro de inadimplentes, o que ocasiona abalo no crédito e restrições no mercado pelo prazo de 05 (cinco) anos, além de ser causa interruptiva da prescrição.

Ademais, o protesto no Brasil não se restringe tão somente a títulos de crédito, mas abrange também outros documentos de dívida, de modo a abarcar muitas situações do cotidiano na busca de solucionar, de maneira alternativa, eventuais problemas de inadimplência, conforme será demonstrado a seguir.

Apenas para que se tenha ideia da amplitude dos títulos protestáveis no Brasil, cite-se o contrato de aluguel, alienação fiduciária, arrendamento mercantil, débitos condominiais, honorários advocatícios, confissão de dívida, termo de acordo, entre muitos outros, cujo rol pode ser consultado no sítio <https://www.protesto.net.br/home.php?ac=titulos protestaveis>, mantido pelo SCPT-SP - Serviço Central de Protesto de Títulos - Distribuidor do Município de São Paulo - Títulos Protestáveis.

O ordenamento jurídico português, por sua vez, preceitua a letra como principal título objeto de protesto ao lado de livranças, cheques, extratos de fatura e outros títulos que a lei sujeite a protesto, porém está muito distante de se igualar ao rol de títulos protestáveis autorizados no Brasil. Dessa feita, depreende-se que a área de atuação do protesto em Portugal é bem limitada quando comparada ao Brasil.

\subsection{Breves notas sobre o procedimento brasileiro de protesto}

De acordo com a dinâmica procedimental, os documentos que podem ser apresentados a protesto devem gozar de certeza, liquidez e exigibilidade. Este é o requisito 
primário para que haja o regular trâmite do título junto ao tabelionato com atribuição de protesto, seja título de crédito seja documento de dívida.

Certeza significa que não há dúvidas quanto à existência da dívida, seja ela materializada por um título de crédito ou por outro documento de dívida.

Liquidez diz respeito à possibilidade de aferição de valor monetário, ainda que seja por cálculo matemático. Todavia, o montante devido deve ser passível de conversão em moeda nacional.

Exigibilidade, por sua vez, está atrelada a ideia do vencimento. Enquanto não vencida a dívida, a mesma não pode ser exigida pelo credor. Desse modo, uma vez vencida e não paga, é possível o protesto do título por falta de pagamento.

Pelo procedimento previsto na Lei Federal Brasileira de n. 9.492/97, o protesto por falta de pagamento, modalidade mais comum na prática notarial, é tirado em 3 (três) dias úteis contados do protocolo.

Dentro do tríduo legal, quatro são as hipóteses possíveis de ocorrer: 1- retirada voluntária pelo apresentante antes da efetivação do protesto, chamada de desistência; 2- o pagamento propriamente dito que no primeiro dia útil subsequente é disponibilidade ao credor da dívida; 3- sustação judicial; 4- oposição ao protesto feita pelo próprio devedor elidindo o protesto.

Conforme depreende-se o referido trâmite é rápido sem que se perda a segurança do ato, posto que a primeira providenciada a ser tomada pelo notário é a qualificação formal do título, ocasião em que é verificado se o título ou documento de dívida cumpre os requisitos específicos previstos em lei, e, portanto, está apto ao registro do protesto.

\section{PROTESTO NO SISTEMA PORTUGÊS}

\subsection{Procedimento luso de protesto comparado ao brasileiro}

O protesto no direito português encontra-se disciplinado pelo Código do Notariado (Decreto-Lei $\mathrm{n}^{\mathrm{o}} 207 / 95$, de 14 de agosto) entre os artigos $119^{\circ}$ a $130^{\circ}$. Já o brasileiro possui regime jurídico específico contido na Lei Federal n 9.492/97, que possui 43 artigos.

O primeiro aspecto que deve ser ressaltado é que, de igual maneira em que se exige no Brasil, o título apresentado deve cumprir com todos os requisitos formais presentes em lei 
para que haja a deflagração do procedimento junto ao serviço notarial com atribuições de protesto.

$\mathrm{Na}$ falta de alguma formalidade essencial e não sendo possível suprimir tal omissão com a legislação aplicável supletivamente, não será a letra admitida ao protesto, nos termos do artigo $119^{\circ}$ do referido diploma legal.

Outra semelhança que merece apontamento é quanto aos títulos escritos em língua estrangeira. Neste caso, tanto a legislação portuguesa quanto a brasileira preveem a necessidade do título vir acompanhado da tradução respectiva. A diferença é que a lei portuguesa dispensa que tal tradução seja feita por notário ou tradutor idóneo sob juramento, enquanto a lei brasileira exige que seja feita por tradutor público devidamente inscrito na Junta Comercial.

Em relação ao lugar do protesto, aplica-se a mesma sistemática tanto em Brasil quanto em Portugal para aferir o cartório com atribuições para o protesto, pois ambos ordenamentos se submetem à Lei Uniforme de Genebra, que dispõe como critérios: 1- lugar de pagamento ou aceite; 2- domicílio do devedor ou aceitante; 3-domicílio do portador ou apresentante.

Em que pese haja previsão expressa de prazo para apresentação do título a protesto no Código do Notariado Português (CNP), na ordem brasileira tais prazos são fruto de construção jurisprudencial, e embora sejam assim fixados, o transcurso de prazo não impede a apresentação a protesto.

Ocorre que após o vencimento do título, evidente que o motivo do protesto somente poderá versar sobre falta de pagamento e não mais falta de aceite, vez que expirado o prazo para tal providência, conforme disciplina a própria Lei Uniforme de Genebra.

Nesse viés, prevalece que não cabe ao notário investigar a prescrição ou decadência do título, de modo que a responsabilidade do protesto recai sobre o apresentante. Conclui-se, portanto, que a defluência do prazo para apresentação não impede o protesto tanto no Brasil quanto em Portugal, até porque o apresentante pode ter interesse em fazer prova da interpelação ou de outra circunstância que não somente o pagamento.

Quanto às notificações dos responsáveis pelo pagamento ou aceite, no Brasil esta, como regra, é feita mediante intimação pessoal no endereço fornecido pelo apresentante. Dessa feita, um funcionário do cartório ou preposto comparece no endereço do devedor para intimá-lo na sua pessoa ou de quem se disponha a receber por ele acaso ausente. 
A notificação no Brasil, todavia, circunscreve-se aos devedores principais do título, diferente de Portugal que abrange todos os responsáveis perante o portador, donde infere-se que estão abrangidos endossatário, avalista, entre outros coobrigados.

Essa falha brasileira merece reparo, pois por meio da notificação dos demais coobrigados aumentam-se as chances da solvência da dívida desvinculada do constrangimento de ser demandado judicialmente, muitas vezes de modo coativo através da penhora de bens que bastem ao pagamento.

A notificação de todos os coobrigados, portanto, atende o propósito de evitar a judicialização, além de viabilizar um método menos gravoso e oneroso de recebimento do crédito.

Nesse sentido se inclina Nuno Madeira Rodrigues em relação à situação do avalista, o qual defende que muitas vezes o avalista procederia ao pagamento voluntário da dívida por meio do protesto, evitando assim o congestionamento dos Tribunais, com o que concordamos:

Diversas vezes somos confrontados com casos nos quais o portador não efectua o protesto e acciona judicialmente o avalista, sendo certo que tal gera situações em que este nunca chegou a ser interpelado, e vê-se arrastado desprevenidamente para um litígio judicial. Mais, casos há em que por os valores em causa permitirem a imediata nomeação de bens, v.g. as acções sumárias, o avalista pode até ser surpreendido por uma penhora sem sequer ter conhecimento do que se passa, situação que, a nosso ver, se afigura como manifestamente estranha e penalizadora (RODRIGUES, 2005, p. 66).

Interessante notar que em Portugal a notificação de protesto se dá via postal por meio de carta com aviso de recebimento remetida ao endereço do responsável. Além disso, incumbe ao apresentante arcar com os custos da intimação, vez que o artigo $124^{\circ}$ do CNP exige que a letra venha acompanhada das cartas-aviso necessárias às notificações a efetuar.

No Brasil, entretanto, em que pese cada Estado tenha regulamentação própria, predomina a gratuidade do protesto ao apresentante, a qual engloba todo o procedimento a ser desencadeado junto ao serviço notarial, inclusive as intimações a serem realizadas.

Ademais, como já dito, a notificação é via de regra pessoal, o que representa uma garantia ao obrigado pelo título de ser configurado em mora dessa forma. Somente se autoriza no Brasil a notificação por carta quando o devedor é domiciliado em Comarca diversa da do serviço notarial, dada a impossibilidade de se fazer a intimação em sua pessoa.

Devidamente notificado, o obrigado pela letra tem o direito de expor por escrito as razões pelas quais deixou de conferir o seu aceite ou pagamento, conforme o caso. 
Tal faculdade aplica-se tanto no instituto brasileiro, quanto no português, de modo a propiciar uma justificativa pelo notificado, escusa esta que deverá ser recebida pelo notário, que por sua vez a fará constará no instrumento de protesto.

Referida providência, embora pouco utilizada na prática, tem relevância na solução da divergência, vez que o título que está sendo cobrado pode não estar de posse do seu portador originário, ter sido objeto de endosso e ostentar algum vício desconhecido pelo atual titular.

Assim sendo, a possibilidade de resposta ao protesto é o meio adequado também para evitar a instauração de demanda judicial destituída de legitimidade para cobrança de dívidas.

Quanto ao prazo, enquanto no Brasil podemos defini-lo como exíguo - 3 dias úteis a contar do protocolo, ou seja, da apresentação. Tal prazo somente poderá ser prorrogado em situações excepcionais quando por exemplo a intimação do devedor somente ter sido feito no último dia do tríduo legal.

Neste caso a lei permite a prorrogação por mais um dia útil para viabilizar o pagamento. Além desta hipótese, compete ao notário justificar no instrumento do protesto o desatendimento do prazo com a especificação dos motivos, os quais devem ser relevantes como força maior, horário de expediente anormal no cartório, entre outros.

Em Portugal este prazo é um pouco mais flexível, podendo ser lavrado o protesto dentro de cinco dias a contar da expedição da carta para a notificação até o $10^{\circ}$ dia a contar da apresentação, nos moldes do artigo $126^{\circ}$ do CNP.

No que diz respeito ao instrumento do protesto, enquanto em Portugal este é ser lavrado em face de todos os coobrigados pela letra, no Brasil a lei somente permite contra o devedor principal. Lógico que se a lei portuguesa permite a notificação de todos os responsáveis, nada mais justo que os mesmos figurem no termo de protesto.

Tanto o Brasil quanto Portugal determinam que os protestos devem ser lavrados de acordo com a ordem cronológica de apresentação. O ordenamento brasileiro, aliás, desconhece qualquer hipótese que excepcione esta regra, a qual é de observância obrigatória. Já em Portugal, em havendo urgência fundamentada, o notário pode desrespeitar este critério temporal, protestando com prioridade títulos apresentados em momento posterior a outros.

\subsection{O sistema atual de cobrança de dívidas no direito português}


Tanto Brasil quanto Portugal são signatários da Lei Uniforme relativa às letras e livranças, estabelecida pela Convenção assinada em Genebra, em 7 de Junho de 1930, conforme já aclarado.

Em Portugal a referida lei é regulamentada pelo Decreto-lei 26.556 de 30 de abril de 1936, que em seu artigo 44 prevê que: “A recusa de aceite ou de pagamento deve ser comprovada por um ato formal (protesto por falta de aceite ou falta de pagamento)."

Conforme lição de Paulo Olavo Cunha (2010, p. 290), o protesto é um ato formal com a finalidade de garantir a ação contra endossantes, sacador e outros coobrigados, nos termos do artigo 43 do Decreto-lei 26.556 de 1936.

O protesto, de acordo com o ordenamento jurídico português, é ato declaratório que comprova a circunstância de falta de aceite ou de pagamento principalmente para assegurar o exercício de direitos cambiários pelo credor.

De fato, se nos restringirmos a interpretar o disposto na Lei Uniforme de Genebra que rege a matéria, de maneira literal, o direito português o segue à risca. $\mathrm{O}$ direito brasileiro, por sua vez, vislumbrou no protesto, mediante certa desnaturalização do instituto, uma forma de cobrança administrativa de dívidas, o que deveras tem se mostrado bastante efetivo na realidade no combate à inadimplência e à morosidade judicial.

A diferença basilar entre os ordenamentos comparados é que na prática em Portugal dispensa-se o protesto para fins de execução de dívidas como regra, enquanto no Brasil incentiva-se o protesto na tentativa de recebimento mais célere afastado da atuação jurisdicional, em que pese, conforme já abordado, que os títulos de crédito tenham por sua natureza jurídica força executiva.

Conforme lição de Pedroso, Trincão e Dias (2001, p. 406): “Tribunais não são o único recurso de uma política pública de justiça, mas integram uma nova relação (alternativa, complementar e/ou substitutiva) entre o judicial e o não judicial.”

A partir desta noção, resta claro que compete aos aplicadores do direito buscar meios alternativos à solução de litígios. Ações que envolvem cobrança são consideradas de baixa complexidade e não exigem, portanto, um esforço intelectual dos juízes para que sejam impulsionadas e concluídas, vez que envolvem, basicamente, medidas de constrição de património para pagamento dos valores devidos. 
Por essa razão defende-se neste trabalho que se Portugal não concebe por bem em adotar o modelo brasileiro para cobrança de dívidas por meio do serviço privativo de protesto ou notarial, outra forma deve ser pensada para vencer a crise do Poder Judiciário.

Isso se justifica na medida que, embora exista em Portugal a figura da execução fiscal por órgão integrante da Administração Tributária, local em que tramita o processo, nas ações envolvendo a Fazenda Pública de um lado e o contribuinte de outro, nos moldes do Decreto-lei de $n^{\circ} 433 / 99$ e do Código de Procedimento e Processo Tributário de Portugal (CPPT), tal medida não é suficiente para solucionar o problema da morosidade judicial.

Nesse sentido, somos adeptos da corrente que entende que ao Judiciário somente as causas de maior relevância devem ser por ele solucionadas à luz de todo o já defendido até aqui.

O sistema português, embora possa ser considerado um avanço na cobrança de débitos, fica adstrito somente às hipóteses em que o exequente seja pessoa de direito público, o que deixa de fora inúmeras ações envolvendo execuções por quantias entre particulares, que poderiam ser solucionadas, de igual maneira, sem intervenção convencional do Poder Judiciário.

Outrossim, acaso suscitada no bojo do processo administrativo alguma temática sujeita à reserva jurisdicional, haverá forçosamente a manifestação do Estado-juiz nos autos, providência de causará atrasos no procedimento.

Daí depreende-se que em verdade referido processo possui natureza mista (judicial e administrativo), não resolvendo por completo a adoção de meios alternativos à resolução de interesses contrapostos alheios ao Judiciário. Inegável também a ausência de imparcialidade num processo de execução extrajudicial em que o credor também é o executor de medidas para satisfação de seu crédito. Nesse rumo, a doutrina portuguesa crítica o modelo utilizado, a exemplo de Rui Duarte Morais, que assim se manifesta:

Fazendo um breve excurso, diremos que existe aqui um elemento perturbador: é o próprio exequente, a administração fiscal, quem pratica certos (a maioria) actos processuais. Aparentemente é ela quem executa o seu próprio crédito. Esta aparência, muito embora não correspondendo no plano jurídico a uma confusão entre duas posições do Estado (Estado credor e Estado julgador), é indesejável pelo modo como prejudica a imagem pública dos Tribunais Tributários (...) (MORAIS, 2005, p. 39). 
Apenas fazendo o contraponto, no Brasil há separação das esferas judicial e administrativa e quando não seja possível a recuperação da dívida ativa por intermédio do protesto, haverá a distribuição de execução fiscal pela Fazenda Pública, enquanto em Portugal o título não pago é submetido de imediato ao processo administrativo não contencioso.

A melhor solução, todavia, parece não ser o modelo brasileiro de protesto, tampouco a justiça fiscal administrativa portuguesa. Através dos estudos relativos a formas alternativas de composição verificou-se o modelo francês que prevê uma entidade autónoma encarregada de praticar todos os atos concernentes à execução do débito.

Por meio deste sistema, um terceiro órgão, que não é o Judiciário, tampouco o notário ou o próprio Estado, realiza todas as medidas necessárias para constrição de bens e recebimento da dívida.

A diferença central em relação aos dois padrões já estudados é que o processo é realizado totalmente abstraído do Poder Judiciário e abrange tanto dívidas públicas quanto privadas.

No Brasil poderíamos quiçá imaginar um notário com atribuições específicas para em não havendo o pagamento no serviço de protesto, ter poderes para, a pedido do interessado iniciar o procedimento de execução de dívidas propriamente dito.

Tal conduta, em termos práticos, vem ao encontro dos anseios brasileiros no sentido de conferir efetividade e celeridade ao recebimento de dívidas em contraste com o panorama atual dotado de morosidade e burocracia judicial.

\section{FUNÇÕES IRRADIANTES DO PROTESTO NA ATUALIDADE}

\subsection{Funções do protesto e a sua relação com a pacificação social}

Pelo já exposto, podemos afirmar que a principal função do protesto é, sem embargo, probatória e certificativa-publicitária, conforme leciona Nuno Madeira Rodrigues (2005, p. 58), que assim conceitua o instituto como "um acto jurídico declarativo destinado a comprovar e dar conhecimento de falta de pagamento de determinado título".

Se por um lado o notário certifica a ausência de aceite ou pagamento, por outro ele também dá conhecimento a terceiros dessa circunstância por meio de certidão quando solicitado por qualquer interessado, afinal, o protesto é um ato público. 
Além da possibilidade de qualquer pessoa obter certidão no serviço de protesto competente para verificar se há alguma pendência em nome de uma pessoa, referida função publicitária propaga efeitos no mercado financeiro no interesse de toda à coletividade e sob esta perspectiva o protesto permite acautelar as pessoas antes de celebrar entre si negócios jurídicos. Conforme ensina Santos (2012, p. 186), “o aspecto mais relevante quanto às variações existentes nos diversos ordenamentos é, sem dúvida, a publicidade do protesto. Nesse particular, o Brasil seguiu o modelo italiano, de ampla publicidade".

Enquanto no Brasil este efeito ocorre pela remessa de informações a respeito de protestos aos órgãos de proteção ao crédito, que disponibilizam a consulta agrupada a nível nacional para particulares e empresas privadas como também atualiza os estabelecimentos bancários, o que auxilia no manejo de concessão e abalo no crédito.

Tal ordenação permite que o fato da inadimplência seja cognoscível a terceiros, que uma vez cientes deste tipo de esclarecimento consigam antever os riscos que circundam eventual ajuste a ser transacionado. Tal noção permite uma melhor de encargos e taxas de juros tendo em vista as experiências anteriores mantidas pelo proponente.

Em Portugal, de igual forma, a publicidade também ocorre no âmbito do serviço notarial, porém diversas instituições de crédito dispõem de acesso por meio do sistema financeiro que é efetuado pela Central de Responsabilidade de Crédito.

Sobre o assunto, nos ensina Sérgio Luiz José Bueno:

Assim, é fato que o protesto tem o legítimo efeito de gerar o abalo no crédito do devedor, e é esse um dos principais fatores que levam a altos índices de satisfação da obrigação, pois muitas vezes a interrupção do crédito leva o inadimplente a abandonar sua conduta protelatória para solver a dívida (BUENO, 2017, p. 69).

A obrigatoriedade de apresentação a protesto repousa-se no artigo 44 da Lei Uniforme de Genebra que assim dispõe: “A recusa de aceite ou de pagamento deve ser comprovada por um ato formal (protesto por falta de aceite ou falta de pagamento)."

A partir do protesto não há como eventual obrigado pela dívida imiscuir-se da responsabilidade alegando desconhecimento ou falta de interpelação, sobretudo em relação ao avalista, conforme nos esclarece Paulo Sendin:

[...] o avalista assumiu a responsabilidade por uma eventual recusa desse pagamento. Mas uma tal responsabilidade não se constitui com a simples 
ocorrência desse facto. É necessário que o portador possa prová-la pelo meio de prova admitido na L.U. - o protesto (SENDIN, 1991, p. 102).

Mais uma função do protesto é a interpelação do devedor. Evidente que a partir do protesto o obrigado pelo título tem ciência inequívoca da cobrança da dívida pelo credor, sendo a lavratura do instrumento do protesto marco inaugural da mora por meio da recusa do pagamento.

Em que pese a natureza do protesto seja a rigor de ato que demonstra a inadimplência, nada obstante, se traduz em um meio, à disposição do credor, de recebimento de dívidas, de maneira segura e eficaz.

Talvez neste viés o instituto do protesto seja um dos melhores exemplos de solução pacífica de conflitos no âmbito das serventias extrajudiciais, uma vez que permite a cobrança de dívidas por um meio juridicamente idôneo.

Já em Portugal podemos afirmar que isso ocorre de maneira indireta, vez que não há uma cobrança propriamente dita pela serventia notarial, mas uma notificação a respeito de um título não aceito ou não pago ao devedor.

Em Portugal, desde 2003, foi introduzida a figura do "agente de execução", misto de profissional liberal e funcionário público, ao qual foram delegadas as diligências inerentes à execução - atos instrumentais que acabam por ocupar o trabalho nos tribunais. Cite-se como exemplo a citação, as notificações, atos de penhora, venda e pagamento - tudo isso submetido ao controle judicial a posteriori do juízo da execução competente (GARCIA, 2013, p. 01, apud GARSON, 2012, p. 12).

No entanto, em que pese não possa haver a solvência da dívida em cartório, o credor poderá interromper o procedimento de protesto, mediante desistência, hipótese em que, via de regra, presume-se a superveniência de uma composição amigável entre credor e devedor.

O modelo português, sob este aspecto, deveria ser revisto para acrescer a possibilidade de pagamento diretamente em cartório, haja vista que tal providência teria o condão de estimular o cumprimento da obrigação desvinculada da atuação judicial.

Por vezes dentro do prazo do procedimento do protesto o devedor não consegue localizar o credor em tempo de solver o encargo que lhe incumbe, mas teria condições de fazê-lo por intermédio do pagamento em cartório ou instituição bancária autorizada. Assim, fica a sugestão a ser agregada ao sistema português no intuito de contribuir com a pacificação social através do decréscimo de demandas judiciais. 
No Brasil, com o alargamento do rol dos títulos suscetíveis a serem protestados, considerando que aplica-se a mesma sistemática antes restrita a títulos de crédito típicos a quaisquer outros documentos de dívida, o resgate de dívidas, e portanto, a resolução de demandas em potencial foi sensivelmente aumentada.

Vale acrescer que no Brasil, como exemplo do adotado pelo Estado de São Paulo, o serviço de protesto é gratuito, ou seja, o credor não tem nenhuma despesa ao apresentar títulos a protesto, de forma a estimular a utilização e difusão do instituto.

O cartório, neste caso, apenas recebe as taxas devidas no caso de pagamento da dívida, e consequente, retirada do protesto, razão pela qual o notário se esforçará de todas as formas para localizar o responsável e obter o pagamento.

Some-se isso ao facto de que os cartórios com atribuição de protesto no Brasil estarem aptos a celebrar convênios com diversas instituições público e privada para recepção de títulos por meio eletrônico, o que vem aumentado sensivelmente o volume de serviço nos últimos anos.

Talvez se tal permissivo fosse de igual maneira aceito em Portugal, o serviço de protesto teria maior repercussão prática do que na atualidade, vez que pelo sistema vigente fica à mercê da apresentação física por meio de particulares ou estabelecimento bancários e condicionado ao pagamento das taxas cartorárias.

Outra medida que auxiliaria na utilização pelos usuários é a abolição do dispositivo $121^{\circ}$ do Código do Notariado Português que prevê que a apresentação das letras a protesto necessariamente deve ocorrer até uma hora antes do período regulamentar do serviço notarial.

Vale ressaltar que a legislação brasileira permite a recepção de títulos até o final do expediente, de modo que dentro do horário regulamentar o usuário pode apontar títulos a qualquer momento, e por meio eletrônico, até mesmo depois do expediente. Isso permite uma melhor utilização da organização deste serviço em prol da comunidade.

Outrossim, com a celeridade e segurança oferecidas por este serviço, é possível a solução de diversos litígios, que acaso não existente esta alternativa, necessariamente teriam de ser submetidos ao Poder Judiciário.

Embora em exíguo prazo, o serviço notarial de protestos corresponde ao pagamento estimado, conforme pesquisas oficiais, de $30 \%$ (trinta por cento) das dívidas ativas, percentual 
significativo se comparado ao número de ações de cobrança que são evitadas por parte do Poder Público através da utilização do expediente do protesto. ${ }^{4}$

Usando como referência o ano de 2016, os cartórios de protesto no Brasil devolveram à economia o montante em torno de 6 bilhões de reais, conforme nos informa o advogado Marco Aurélio de Carvalho. ${ }^{5}$

Este mesmo jurista acrescenta: "Sem falar no instrumento de protesto, cuja elevada eficiência na resolução de conflitos relacionados à recuperação de créditos evita que tais litígios cheguem aos tribunais.",

Em atenção ao princípio da justiça preventiva na atuação do notário, Loureiro (2018, p. 1068) ensina que o mesmo se apresenta como "essencial para a garantia da paz social, mediante a prevenção de litígios, um dos objetivos fundamentais do Estado". Nesse sentido, faz-se de elevada importância a atuação dos Cartórios de Protestos por meio da atuação dos Tabeliães de Protestos como meios efetivos de se auferir o recebimento de valores por meio do seu sistema de protesto de títulos e assim garantir que o menor número possível de demandas alcance os tribunais por meio de ações judiciais.

\subsection{Cartórios de Protesto e sua atuação na renegociação e quitação de dívidas do cidadão}

É cediço que a cobrança de dívidas junto ao Poder Judiciário é um problema que envolve inúmeros países, entre eles Brasil e Portugal. O problema fica mais evidente quando analisada o número de execuções fiscais pelo poder público.

\footnotetext{
${ }^{4}$ GOBBI, André e Bruno Teixeira. O protesto de títulos e a sua eficiência na recuperação de créditos -2 . Disponível em: https://spcm.com.br/blog/o-protesto-de-titulos-e-sua-eficiencia-na-recuperacao-de-creditos-2/. Acesso em: 24 jan. 2018.

${ }^{5}$ CARVALHO, Marco Aurélio de. Acabar com os cartórios causaria insegurança e ineficiência nos serviços públicos. Disponível em: https://www.conjur.com.br/2018-set-10/opiniao-acabar-cartorios-traria-insegurancajuridica. Acesso em: 10 set. 2018.

${ }^{6}$ CARVAlHO, Marco Aurélio de. Acabar com os cartórios causaria insegurança e ineficiência nos serviços públicos. Disponível em: https://www.conjur.com.br/2018-set-10/opiniao-acabar-cartorios-traria-insegurancajuridica. Acesso em: 10 set. 2018.
} 
O poder público é um dos principais litigantes em juízo, possuindo uma quantidade substancial de demandas ajuizadas para reaver valores devidos por meio de certidões da dívida ativa.

Em uma escala de prioridades, o contribuinte prioriza o pagamento de instituições financeiras, cujos juros e encargos são altíssimos, de serviços essenciais, já que não é possível viver dignamente sem tais prestações, relegando o pagamento de tributos para a última classe de dívidas a serem soldadas.

Caso recente diz respeito às certidões de dívida ativa, que são títulos executivos dotados de presunção de certeza e liquidez e por isso o Superior Tribunal de Justiça no Brasil (STJ) por muito tempo entendia ser inócuo o protesto das mesmas. Acrescente-se que a lei brasileira de execução fiscal prevê que a cobrança deve ser necessariamente judicial.

Pois bem. Ocorre que inexistia dispositivo legal que vedasse o protesto das certidões de dívida ativa e por muito tempo havia uma polêmica sobre a possibilidade ou não do encaminhamento a protesto de tais dívidas.

O desfecho desta celeuma sobreveio em 2012, por meio de uma alteração legislativa, que consagrou, por fim, a viabilidade de protesto das certidões de dívida ativa, as quais, embora dotadas de presunção de certeza e liquidez, tem sido objeto de recuperação de maneira administrativa, evitando-se a judicialização de milhares de execuções fiscais.

Protesto, nesse viés, é meio idôneo e capaz de coibir o descumprimento da obrigação, pois tem por condão o estímulo no adimplemento da dívida.

A ideia do protesto é pedagógica, ensinando aos mal pagadores que o descumprimento de avenças geram consequências, sobretudo, como será abordado mais adiante, a restrição de crédito no mercado.

Sob esta ótica, é preciso evoluir para se verificar meios alternativos que não o Judiciário. Além disso, encontra-se implicitamente contido, além do clamor social pela desjudicialização, o interesse coletivo em inibir a inadimplência de eventuais devedores.

Referida medida acarreta a diminuição no número de demandas de execuções propostas e melhora a prestação jurisdicional. Outrossim, o pagamento em cartório não sujeita o devedor ao ônus de ter seus bens penhorados pela Justiça, situação deveras menos gravosa a ele.

Em recente normatização o Conselho Nacional de Justiça - CNJ, editou o Provimento $\mathrm{n}^{\circ} 72$, de 27 junho de 2018 que dispõe sobre medidas de incentivo à quitação ou à 
renegociação de dívidas protestadas nos tabelionatos de protesto do Brasil. O referido dispositivo disciplina que as medidas de incentivo à quitação ou à renegociação de dívidas protestadas nos tabelionatos de protesto serão medidas prévias e facultativas aos procedimentos de conciliação e mediação.

Em Guimarães (2018, p. 88) Alexandre Chini Neto, juiz auxiliar da Corregedoria Nacional, relata que "A segurança jurídica é o que notabiliza e dignifica a atividade dos cartórios". Nesse sentido, todas as medidas que vem sendo incorporadas ao ordenamento jurídico nacional por meio do próprio Código de Processo Civil vigente e demais regulamentações do $\mathrm{CNJ}$ que regulamentam a atuação de conciliadores e mediadores extrajudiciais são apenas o retrato dos anseios da sociedade que está exigindo mais celeridade na resolução de conflitos e controvérsias. E a atuação dos Cartórios de Protesto na intermediação no recebimento de dívidas atuando como elo entre devedor e credor é apenas um desses reflexos.

\section{CONSIDERAÇÕES FINAIS}

As explanações ditas observam a importância de evoluir a abrangência do protesto para alcançar meios alternativos de recebimento do crédito que não o meio judicial, posto que existe uma necessidade social pela desjudicialização.

Ainda que comparado com outros ordenamentos jurídicos o instituto do protesto mantem sua essência de meio complementar de auferir créditos inadimplidos por meio da persecução e da publicidade que se dá ao não pagamento do título. Em que pese ser tratado de modo singular nos demais ordenamentos, o objetivo final é o mesmo, qual seja a pacificação de um conflito pelo desconforto gerado pelo não pagamento da dívida contraída por meio de um título.

O grande fluxo de negócios que são travados na sociedade moderna justifica um processamento célere de demandas que sejam originadas pelo descumprimento de acordos e contratos. Assim, a inadimplência no pagamento é uma das causas que geram inúmeros processos que se alongam por anos no Judiciário em busca de solução, muitas vezes sendo arquivados por falta de acordo ou mesmo pagamento. De tal modo que soluções alternativas que gerem oportunidades de conciliação e opções de satisfazer as necessidades do credor em 
receber os valores que lhe cabem são enfim muito benéficas em uma sociedade cada vez mais plural na sua forma de ser, e no modo de ser relacionar e firmar contratos.

Por fim, a publicidade que se alcança com o protesto do título inadimplido é apenas uma das formas de se inibir que se proliferem negócios travados com margem para não serem cumpridos por uma das partes. É nesse sentido que a publicidade do protesto protege as relações negociais. Não se pretende tão somente alimentar cadastros públicos e particulares de devedores, o que se almeja é a pacificação social por meio da redução de processos judiciais e demandas que envolvam satisfação de crédito.

Nossa legislação pátria evoluiu positivamente em relação aos meios alternativos de cobrança de dívidas. Assim, o arcabouço que alimenta e sistematiza a atuação dos tabelionatos de protesto é um exemplo de como os mesmos podem atuar de forma completa na recuperação de crédito.

\section{REFERÊNCIAS}

BUENO. Sérgio Luiz José. Tabelionato de Protesto. 3. a ed. São Paulo: Saraiva, 2017.

CARVALHO, Marco Aurélio de. Acabar com os cartórios causaria insegurança e ineficiência nos serviços públicos. Disponível em: https://www.conjur.com.br/2018-set10/opiniao-acabar-cartorios-traria-inseguranca-juridica. Acesso em: 10 set. 2018.

CNJ. Provimento n. 72, 27 jun. 2018. Dispõe sobre medidas de incentivo à quitação ou à renegociação de dívidas protestadas nos tabelionatos de protesto do Brasil. Disponível em: http://www.cnj.jus.br/busca-atos-adm?documento=3502. Acesso em: 01 abr. 2019.

CUNHA. Paulo Olavo. Lições de Direito Comercial. Lisboa: Almedina, 2010.

GARCIA, Raquel Duarte. Importância dos tabelionatos de protesto como instrumento de desjudicialização das cobranças de créditos no Brasil. Revista Jus Navigandi. Teresina, ano 18, n. 3690, 8 ago. 2013. Disponível em: https://jus.com.br/artigos/25135. Acesso em: 1 abr. 2019.

GARSON, Samy. A viabilidade da desjudicialização do processo de execução. Trabalho apresentado como requisito para a conclusão do Mestrado em Processo Civil na Faculdade de Direito de Coimbra. Disponível em: http://www.sgaa.adv.br/downloads/a_ceu.pdf. Acesso em 1 abr. 2019.

GOBBI, André e Bruno Teixeira. O protesto de títulos e a sua eficiência na recuperação de créditos. Disponível em: https://spcm.com.br/blog/o-protesto-de-titulos-e-sua-eficienciana-recuperacao-de-creditos-2/. Acesso em: 24 jan. 2018. 
GUIMARÃES, Frederico. Cartórios de Protesto já podem atuar na renegociação e quitação de dívidas do cidadão. Revista Cartórios com você. São Paulo, v. 1, n. 14, p. 82-97, ago./out. 2018 .

LOUREIRO, Luiz Guilherme. Registros públicos: teoria e prática. 9. ed. Salvador: Editora Juspodivm, 2018.

MORAIS, Rui Duarte. A execução fiscal. Coimbra: Almedina, 2005.

PEDROSO, João; TRINCÃO, Catarina e DIAS, João Paulo. Percursos da informalização e da desjudicialização - por caminhos da reforma da administração da justiça (análise comparada). Coimbra: Universidade de Coimbra, 2001. Disponível em: http://opj.ces.uc.pt/pdf/6.pdf. Acesso em: 10 mai. 2018.

RODRIGUES. Nuno Madeira. Das Letras: Aval e Protesto. 2. ed. Coimbra: Almedina, 2005.

SENDIN. Paulo. A natureza do Aval e a questão da necessidade ou não do Protesto para accionar o Avalista do Aceitante. Coimbra: Almedia, 1991.

SANTOS, Reinaldo Velloso dos. Apontamentos sobre o protesto notarial. São Paulo, 2012. 244 f. Dissertação (Mestrado em Direito) - Universidade de São Paulo, São Paulo, 2012. 